\title{
Debt Burden of Constituents of the Russian Federation and Its Determinant Factors
}

\author{
Sabitova Nadia \\ Kazan Federal University, Institute of Management, Economics and Finance, Kazan, 420008, Russia \\ Email: sabitovanm@mail.ru \\ Nikonova Elena
}

Kazan Federal University, Institute of Management, Economics and Finance, Kazan, 420008, Russia

Doi:10.5901/mjss.2014.v5n24p216

\begin{abstract}
Expansion of expenditure obligations of the Russian Federation constituents and municipalities, which results in growing pressure on expenditure of territorial budgets, with preservation of current practice of revenue distribution between budgets of Russian budgeting system and reduction of cheap budget credits granted to regions - the situation when debt finance of budget expenditure and, accordingly, the increasing debt burden on regional budgets, are of current concern. This article analyses debt burden of Russian regions taken in conjunction with its prime budget and economic indices. On the basis of analysis we draw certain conclusions on factors that determine the level of debt burden and tendencies in regional debt behaviour, raise problems which, if solved successfully, will provide for improvement of debt situation in constituents of the Russian Federation.
\end{abstract}

Keywords: public debt of constituent of the Russian Federation; municipal debt; total regional debt; debt burden; regional and municipal debt management; loan and debt management system; regional debt policy

\section{Introduction}

The Russian State Programme of Enhanced Management of Public Finance (hereinafter referred to as the State Programme) was approved by Directive of the Government of the Russian Federation of August 30, 2013; the date of December 31, 2020 was specified as project finalization date. The document has specified eleven major targets of state policy in the sphere of public finance management, one of stated priorities is "effective management of public debt and financial assets of the Russian Federation, aimed at preservation of high-scale debt solvency that had been reached in the recent years and maintaining Russia's credit ratings of investment category at a high level. But it is important to realize that maintenance of debt solvency of the Russian Federation is a problem which can not be considered without regard to debt situation in constituents and municipalities of the Russian Federation That's why regular monitoring of budget debt burden of the Russian Federation constituents and local budgets with full compliance of budget restrictions set forth by the Budget Code of the Russian Federation, debt optimisation is an "additional condition" of successful implementation of State programme events within the framework of the above stated priority. Moreover, formation of conditions for minimization of state debt growth risks of RF constituents and municipal debt was defined in the above document as one of the "principal tendencies" of public finance management development.

The recent years situation with growth of debt burden on budgets had predestined considerable academic interest to debt management problems in the following research papers: Schularick, M. in his paper concluded that the costs of wars have been the main driver of public debt in the Western World during the modern era [1], Maltritz, D., A. Bühn and S.Eichler learned that the simultaneous consideration of sovereign yield spreads and Standard and Poor (S\&P) ratings may help to improve the identification of the latent country default risk [2], Bernoth, K., J. Von Hagen, L. Schuknecht in their paper studied bond yield differentials among EU government bonds on the basis of a unique data set of issue spreads in the US and DM (Euro) bond market [3], Paudyn, B. explored the contribution of credit rating agencies to the constitution of the politics of limits underpinning the European sovereign debt crisis [4], Mody, A. detected the necessity of debt restructuring to compensate for the inflexibility due to fixed exchange rates [5].

Different aspects of regional debt policy were represented in papers by E.A. Ermakova, A.D. Andryakov $[6,7]$ and others. However, the changing debt situation, specific nature in different regions necessitate further deep research in this sphere. 


\section{The Main Part}

Most constituents of the Russian Federation and municipal formations always had some scope of debts, but till financial crisis of 2008-2009 the situation with debts was not so crucial. After 2008 debts of constituents of the Russian Federation and municipal formations were rising constantly, which is shown in Figure 1.

For the whole considered in Figure 1 period, total state debt of constituents of the Russian Federation and municipal formations increased by 2.3 times. Only for the year 2009 debt had increased half as much. Further on we can observe some reduction of total debt growth rates of constituents of the Russian Federation and municipal formations (in 2010 debt increased to 23,6\%, in 2011 - to 9,6\%). In 2012 we see increase of debt growth rates, for the said year debt increased to $15,1 \%$. So, the situation with debts of regions and municipalities had changed for worse in 2012 as compared with 2011: total state debt of constituents of the Russian Federation and debt of municipal formations had increased to 209,5 billion rubles. (for comparison, in 2011 the increase was 121,5 billion rubles).

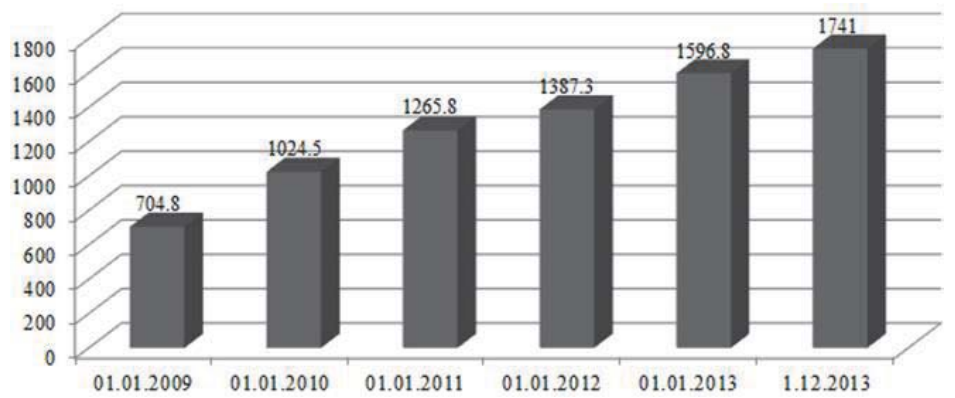

Figure 1. Total state debt dynamics of constituents of the Russian Federation and debt of municipal formations

In Table 1 we have presented the dynamics of main budget and debt indices of Russian regions and municipalities for 2011-2012. According to represented data, rates of debt growth $(115,1 \%)$ had exceeded the rates of total tax and non-tax revenues of consolidated budgets of constituents of the Russian Federation (109,6\%).

Table 1. Dynamics of basic budget and debt indices of Russian regions*

\begin{tabular}{|c|c|c|c|}
\hline Indices & 2011 & 2012 & \begin{tabular}{|c|} 
Index \\
growth rate, $\%$ \\
\end{tabular} \\
\hline \multicolumn{4}{|l|}{ 1. Revenue of consolidated budgets of constituents of the Russian Federation } \\
\hline 1.1.Total revenue, billion rubles & $7,643.9$ & $8,064.5$ & 105.5 \\
\hline 1.2.Revenue net of inter-budgetary transfers from the federal budget, billion rubles & $6,174.0$ & $6,624.3$ & 107.3 \\
\hline 1.3. Tax revenue, billion rubles & $5,273.1$ & $5,800.3$ & 110.0 \\
\hline 1.4.Non-tax revenue, billion rubles & 554.1 & 584.2 & 105.4 \\
\hline \multicolumn{4}{|l|}{ 2. Expenditure of consolidated budgets of constituents of the Russian Federation } \\
\hline 2.1.Total expenditure, billion rubles & $7,679.3$ & $8,343.2$ & 108.7 \\
\hline 2.2. Expenditure net of inter-budgetary transfers from the federal budget, billion rubles & $6,208.9$ & $6,903.0$ & 111.2 \\
\hline 2.3.Investment expenditure, billion rubles & $1,157.6$ & $1,118.7$ & 96.6 \\
\hline 2.3. Share of investment expenditure, $\%$ & 15.1 & 13.4 & $\mathrm{x}$ \\
\hline 2.4.National and municipal debt service expense, $\%$ & 0.99 & 0.89 & $\mathrm{x}$ \\
\hline \multicolumn{4}{|l|}{ 3. Borrowings of constituents of the Russian Federation and municipal formations } \\
\hline 3.1. Public budget loans raised from federal budget, billion rubles & 128.4 & 129.5 & 100.9 \\
\hline 3.2.Raising loans of credit organizations, billion rubles. & 419.9 & 580.4 & 138.2 \\
\hline \multicolumn{4}{|l|}{ 4. Debt indices } \\
\hline 4.1 Total state debt of constituents of the Russian Federation and debt of municipal formations, billion rubles. & $1,387.3$ & $1,596.8$ & 115.1 \\
\hline $\begin{array}{l}\text { 4.2.State debt of constituents of the Russian Federation, billion rubles, } \\
\text { including: }\end{array}$ & $1,171.8$ & $1,351.4$ & 115.3 \\
\hline 4.2.1. Government securities of constituents of the Russian Federation. & 343.9 & 375.4 & 109.2 \\
\hline 4.2.2. Loans raised by constituents of the Russian Federation from credit organizations & 300.0 & 438.2 & 146.1 \\
\hline 4.2.3. Budget loans taken out by RF constituent budget from other budgets of Russian budget system. & 419.2 & 426.1 & 101.7 \\
\hline 4.2.4. State guarantee of the RF constituent & 108.5 & 111.5 & 102.8 \\
\hline 4.3.Debts of municipal formations, billion rubles & 215.5 & 245.3 & 113.8 \\
\hline
\end{tabular}

${ }^{*}$ Compiled by authors on the basis of [8], [9] 
In many respects growth of debt may be explained by increased social commitments, which for most of RF constituents turned to be impossible to meet, thus regions had to borrow money to fulfil their budget commitments. Total loan raised by regions and municipalities from credit organizations had increased in 2012 to 160,5 billion rubles, while budget loans raised from the federal budget had increased only to 1,1 billion rubles.

The scope of tasks imposed on regions have been expanding in recent years. The Russian President's Budget Message on Budget Policy 2014-2016 says about the increased burden on regional and local budgets. The document also states the tendency of negative changes in regional budget expenditure structure, slump of expenditures that have the nature of an investment. Data submitted in Article 1 show that in 2012 expenditure of consolidated budgets of constituents of the Russian Federation, that have the nature of an investment, decreased to 38,9 billion rubles as compared to 2011; their share in total expenditure has decreased from $15,1 \%$ to $13,4 \%$. With reduction of budget investment the total amount of expenditure of consolidated budgets of constituents of the Russian Federation increased to $8,7 \%$.

In total state debt volume of constituents of the Russian Federation and municipal formations, the main part falls on state debt of the Russian Federation constituents - 85\%. In conformity with budget legislation of the Russian Federation, debt commitments of the RF constituent may exist in the form of :

1) obligation for state securities of the RF constituent;

2) budget loans taken out by RF constituent budget from other budgets of RF budget system;

3) credits raised by constituent of the Russian Federation from credit organizations, foreign banks and international financial organizations;

4) obligation for state guarantees of the RF constituent.

Professor E.A. Ermakova offers, (and authors of this paper share her point of view) to grade conditionally specified types of debt commitments in terms of "preferability" and service cost as follows [6]. The first type is state guarantees, which, if present in general scheme of state debt of constituent of the Russian Federation, show the investment nature of debt, that appropriate authorities work with business, thereat region has tangible benefit, since tax revenues increase, new workplaces open, as a rule, actual budget expenditure with such debt are minimal and notional. The second type of debt obligations is budget loans raised by regions from the federal budget; such loan service charges are minimal; budget loans share in total debt amount of the RF constituent may be indicative of both degree of belief on the part of state financial authorities, and of their willingness to strongly support economy of some regions. The third type of debt obligations is government securities of constituents of the Russian Federation (bonds); bonded loan service charges are considerably higher than debt service of the first two types of debt commitment. According to E.A. Ermakova, bonded loans should be the main (if not the only one) source of long-term financial resources raising for regional financial managers. The latest in desirability rating, the most non-transparent and expensive type of loans for constituents of the Russian Federation is bank loan.

Data given in Table 1 show that in state debt profile of the RF constituents at the year-end 2012, loans raised by RF constituents from credit organizations, i.e. "most non-transparent and expensive" come first (33\%); while budget loans raised from federal budget take the second place (32\%), and government securities of RF constituents take the third place (28\%). It is worth to note, that in 2012 government securities of only 32 RF constituent circulated in cumulative portfolio of region debts. Government securities of RF constituents showed $8 \%$ in total debt commitments of the RF constituents. Certainly, region-wise, the debt profile differs considerably.

Against the general growth of total debt of RF constituents and municipalities, debt dynamics in certain regions has a competing character. Our research held on the basis of data given by the Ministry of Finance of Russia, showed that in 2012 only 18 regions of 83 could reduce total debt volume of RF constituent and municipalities (further on referred to as region's cumulative debt, region's consolidated debt): for more than $30 \%$ debt volume has reduced in the Nenets Autonomous District (to 46,7\%), the Irkutsk region (to 46,6\%), Khanty-Mansiisk autonomous district - Yugra (to 39,4\%), the Perm Territory (to $37,4 \%$ ), the Tyumen region (to 31,9\%); the Kamchatka Territory reduced its cumulative debt to $20,4 \%$, the Republic of Buryatia - to 20\%, Moscow - to 19,5\%, the Chechen Republic - to 15,5\%, the Republic of Kalmykia - to $12,5 \%$, the Magadan region - to $11,3 \%$, Republic of Sakha (Yakutia) - to 6,9\%, the Moscow region - to $6,6 \%$, the Rostov region - to 5,4\%, the Republic of Adygeya - to 4,3\%, the Republic of Altai - to 1,9\%; minor decrease of cumulative debt $(0,3 \%)$ is shown by the Kursk region and the Kaliningrad region.

"The leader" in debt increase was the Republic of Ingushetia; due to state guarantees, the total debt of this region increased by 16 times. There is considerable growth of cumulative debt of the Yamalo-Nenets Autonomous District (by 3,3 times), the Republic of Tuva (by 3 times), Saint Petersburg (by 2,5 times), the Chukotka Autonomous District (by 2,2 times).

As we have noted it before, in general in the Russian Federation debts showed larger growth than tax and no-tax 
revenue of consolidated budgets of the RF constituents, but the said tendency was characteristic for just some of regions. So, positive dynamics of tax and non-tax revenue may be observed in all above mentioned constituents of the Russian Federation, which managed to reduce the cumulative debt of the region. Besides, exceeding growth rate of tax and nontax revenue of consolidated budget over growth rate of cumulative debt of region may be observed in the following RF constituents: the Vladimir region, the Sakhalin region, the Sverdlovsk region, the Voronezh region, the Bryansk region, the Astrakhan region, the Arkhangelsk region, the Kaluga region, the Kostroma region, the Republic of Tatarstan and the Republic of North Ossetia-Alania. The volume of tax and non-tax revenue of consolidated budgets of the Rostove region, the Magadan region, the Astrakhan region, the Arkhangelsk region, the Kaluga regions, the Republic of Tatarstan had grown for more than $20 \%$ as compared with 2011. Tax and non-tax revenue to the budget of the Republic of Kalmykia and budgets of republican municipalities had grown to $65 \%$ in 2012 as compared to 2011; in the Sakhalin region such increase made $50 \%$.

When analysing the dynamics of tax and non-tax revenue of consolidated budgets of the RF constituents, it is worth to note that in 2011 incentive mechanism was tested in regards to RF constituents that showed best results in increasing their taxable capacity. In 2012 incentive programme for top-performance constituents continued. At the end of the 2011 year 20 regions received grants of the federal budget for best practice in increasing their taxable capacity, and 25 regions receives the same at the end of the 2012 year. In 2012 among 25 prizewinner constituents only 6 regions of 18 had increased receipt of tax and non-tax payments in their budgets and decreased their cumulative regional debt volume, those were Moscow, the Moscow region, the Tyumen region, the Kursk region, the Magadan region and the Republic of Adygeya. From among the rest 11 RF constituents that demonstrated exceeding growth rate of tax and nontax revenue of consolidated budget over growth rate of cumulative debt of region, only 5 regions were prizewinners, those were the Vladimir region, the Sverdlovsk region, the Voronezh region, the Kaluga region and the Republic of Tatarstan. The rest 14 RF constituents, that received their grants for best practice in increasing their taxable capacity in late 2012 are 12 regions, where debt growth exceeded their tax and non-tax revenue of consolidated budgets, and 2 regions (the Belgorod and Murmansk regions), where cumulative regional debt increased by 1,7 times, while tax and non-tax revenue of consolidated budgets decreased in 2012 as compared to the year 2011(the Belgorod region - to 7\%, the Murmansk region - to 3\%). So, we may draw a conclusion that exceed of growth rate of regional cumulative debt over growth rate of tax and non-tax revenue of regional consolidated budget of RF constituent is not considered a negative trend and does not serve a ground for non-application of incentives in regards to region.

First of all, regions and municipalities should treat loan raising as an effective investment expenditure facility, aimed at meeting strategic goals of socioecomonic development of their territories. Our study showed, that among $65 \mathrm{RF}$ constituents with increased cumulative regional debt, only 33 of them demonstrate positive dynamics of budget investments, 32 regions that increased their debt, have reduced expenditures that have the nature of an investment. Among RF constituents that decreased their cumulative regional debt, demonstrate diverse situation: among 18 regions, 8 demonstrate growth of investment expenditure, and 10 regions show reduction of the same.

In terms of constantly increasing demand in additional financial resources, including investments, which is characteristic to practically all regions and municipal formations of the Russian Federation, waiving loans is impossible to imagine. Moreover, waiving loans in such conditions may result in conversion of debt commitments into overdue accounts payable; such so-called latent loans in the form of outstanding budget commitments cause the chain of creditor indebtedness of economic entities, which adversely effects the economy of region; on the other hand, in case of waiving loans, investment demands in capital expenditure can not be satisfied to the fullest degree due to unavailability of financial resources [10].

In debt burden rating of constituents of the Russian Federation, determined here as ratio of total debt of RF constituent and municipalities to total tax and non-tax revenue of consolidated budget of RF constituent $P \Phi$, the first position is held by Nenets Autonomous District with its minimal debt burden of $0,1 \%$, we should note here that debt of this region is represented only be municipal debts. The last in the rating is the Republic of Mordovia with debt burden of $139,9 \%$. The volume of cumulative regional debt exceeds $50 \%$ of the total total tax and non-tax revenue of consolidated budget in 19 constituents of the Russian Federation.

Appraising in general the situation with debts in Russian regions, authors come to a conclusion that high level of debt burden and positive rates of debt growth can not serve as decisive evidence of ultimate debt situation in one region or another, since much depends on temporal debt structure,on ratio of debt payments and their serviceability in each period of time. Estimate of regional finance management quality in each of RF constituents by the Ministry of Finance of the Russian Federation may serve as indirect prove of our conclusion. At the conclusion of 2012, the following constituents of the Russian Federation with high debt burden have high quality rating of finance management: the Kaliningrad region (74,6\%), the Smolensk region $(69,1 \%)$, the Astrakhan region $(64,4 \%)$, the Republic of Altai $(59,9 \%)$, 
the Novgorod region (51,2\%). And, on the opposite, the number of RF constituents with debt burden index less than $50 \%$, are characterized by low finance management quality: the Republic of Ingushetia (33,7\%), the Oryol Region (38\%), he Chukotka Autonomous District (48,2\%). It is fair to say, however, that not only debt situation is taken into consideration by Ministry of Finance of the Russian Federation in its assessment of regional finance management quality. Comprehensive assessment is done with consideration of the following aspects in regional finance management in RF constituents:1) budget planning; 2) budget administration; 3) state debt management; 4) financial relations with municipal formations;5) public property management and rendering of state services;6) transparency of the budget process.

Our research showed, that not all Russian regions having high level of debt burden are characterized with economic parameters degradation. So, the Astrakhan region with its debt burden of $64,4 \%$, has high industrial index (coming second only to the Voronezh region) - 125,8\%; on the contrary, the Nenets Autonomous District with the lowest debt burden $(0,1 \%)$ shows negative output indices movement (the lowest industrial production index among all regions $89,3 \%)$. For the "rate of investment growth in capital assets" we may give similar examples. The Primorsk Territory is characterized with decrease of capital investments in 2012 as compared with 2011 to 41\%, while debt burden of the region is only 5,7\%. On the contrary, the Republic of Tuva and the Pskov region with their rather high debt burden (49\% $\mathrm{n}$ $48,8 \%$, accordingly), show high capital investment growth rates, as compared with other regions - 131,8\% и 128,2\%, accordingly.

Within the frame of this work, in view of its limited volume, it does not seem possible to carry out analysis of more parameters, describing economic situation of constituents of the Russian Federation.

For the purpose of general apprehension of how economic specialization of regions effects their debt burden, we have arranged all RF constituents in four groups with due regard to economic specialization: "Financial and Industrial Centres", "Export-Oriented Regions", "Rural and Industrial Regions", "Industrial Regions". This grouping is used by RIA Rating Agency when making up social and economic rating of the RF constituents. The study proved that mean debt burden calculated for regions in the group "Export-Oriented Regions" reached only 9,1\%; for regions of "Financial and Industrial Centres" - 16,2\%; for regions of "Industrial Regions" mean debt burden reached 37\%; "Rural and Industrial Regions" group has the highest rate $-43,2 \%$ (though within groups, especially in industrial and rural-industrial regions, we can see a wide spread of rate values).

\section{Conclusion}

Constituents of the Russian Federation differ widely in terms of debt burden. Current debt burden and tendencies in regional debt development are estimated by effect of a group of factors, including:

- first, economic specialization of region, which in large part determines the level of its fiscal capacity. In virtue of historical, geographical, climatic and other objective factors, siting of labour forces in the territory of the Russian Federation was notably uneven, which explains differentiation in the level of regions' fiscal capacity, and, consequently, level of debt burden;

- second, rates of economic development of region. Solution of debt problem directly depends on solution of regional economic growth problem;

- $\quad$ third, approach to state debt management (municipal debt) of RF constituent.

In our opinion, high level of debt burden should not considered as cause of financial problems of regions, the root cause is economic and financial region undermanagement (including debt undermanagement). We can't but agree that the current Russian system of income sources and expenditure commitments differentiation has its downsides. But we should not consider the matters of debt situation in regions and search for solutions only in terms of inter-budget relations reforming.

Development and implementation of measures aimed at investment climate facilitation and improvement of region's investment attractiveness, by authorities of RF constituents is currently top priority task, which, when solved, would result in improvement of debt situation. The Russian President's Budget Message on Budget Policy 2014-2016 says, that "expenditures of constituents of the Russian Federation should be to the fullest extent secured by their own sources of income. Thereat all decisions taken should be thought ahead and cashed-up. Additional financial assistance to constituents of the Russian Federation should go with economical advancement from their own resources". Thus it stresses the importance of regional measures on attracting investments and increase of taxable capacity.

For most Russian regions another important task is to enhance debt management effectiveness, which is impossible without formation of a relevant loan and debt management system. In this connection we should note that within the framework of joint "Regional Fiscal Technical Assistance Project"of the Ministry of Finance of the Russian Federation and the International Bank for Reconstruction and Development, in 2002-2004 consortium composed of 
"Economic Expert Group" Closed Joint-Stock Company and FitchRatings Global Rating Agency had implemented subproject "Regional and Municipal Debt and Contingent Commitment Management System" (the project was implemented with participation of administration of three regions: the Chuvash Republic, the Vologda region and Chelyabinsk region). Experts of consortium have worked out:

- Concept of regional and municipal debt management system reform,

- Standards of regional and municipal debt management (complete package of regulatory and methodology documentation required for introduction of debt management mechanism and procedure),

- Regional and municipal debt management best practice code.

Therefore, all recommendations on formation and functioning of regional and municipal debt management system have been developed in 2004 jointly by Russian and foreign experts on the basis of best foreign practice and considering the Russian context. In the light of the above, we share point of view of A.D. Andryakov, that reforming of regional and municipal debt management institutional system and decision-taking system in debt policy requires political will of regional authorities.

Taking into account debt management method development, in order to create in practical terms a transparent, effective system of regional (municipal) debt management, in the opinion of authors, the following is essential:

- approval of regulatory and methodological documents governing different aspects of debt management;

- use of automation aids for debt obligations recording, servicing and discharge, as well as strategic and operational decisions taking process in development and realization of debt policy;

- training courses for specialists of financial authorities of RF constituents and municipal formations, responsible for debt management in loan raising and debt management.

Only comprehensive approach to all specified above tasks would afford to solve problems of regional budget balance and build up debt capability of RF constituents and municipal formations.

\section{References}

Schularick, M. , December 2012. Public debt and financial crises in the twentieth century. European Review of History, 6: 881-897.

Maltritz, D., A. Bühn, S.Eichler, December 2012. Modelling country default risk as a latent variable: A multiple indicators multiple causes approach. Applied Economics, 36: 4679-4688.

Bernoth, K., J. Von Hagen, L. Schuknecht, September 2012. Sovereign risk premiums in the European government bond market. Journal of International Money and Finance, 5: 975-995.

Paudyn, B., August 2013. Credit rating agencies and the sovereign debt crisis: Performing the politics of creditworthiness through risk and uncertainty. Review of International Political Economy, 4: 788-818.

Mody, A., 2013. Sovereign debt and its restructuring framework in the Eurozone. Oxford Review of Economic Policy, 4: 715-744

Ermakova E.A., 2013. Budgets of Russian Regions: What is to be done? Date Views 25.11.2013. www.budget4me.ru/ob/ faces/newportal

Andryakov A.D., 2004. Sub-federal debt management reform - main directions and development prospects. Date Views 25.11.2013. www.eeg.ru/downloads/VIST/piter_7_09_04.pps?PHPSESSID

Final Statement of Accounting Chamber of the Russian Federation to Report report on the implementation of the federal budget 2011. Date Views 14.12.2013 www.ach.gov.ru/ru/expert/follow-up/?id=897

Final Statement of Accounting Chamber of the Russian Federation to Report report on the implementation of the federal budget 2012. Date Views 14.12.2013 www.ach.gov.ru/ru/expert/follow-up/?id=1053

Economic Expert Group, Fitch Ratings. Debt Management System Project Final report Date Views 14.12.2013 www.fer.ru/rftap/files IRFTAP QCBS 3.4_Final report 1.pdf

Public finance and public policy (Third edition) By Jonathan Gruber. New York: Worth Publishers, 2011.

Barro R (1974)/ Are government bonds net wealth? Journal of Political Economy, 82 (6): 1095-1117.

Barro R. On the Determination of the Public Debt // Journal of the Political Economy. — 1979. — Vol. 87. — № 5.

The Theory of Public Finance: A Study in Public Economy By Richard A Musgrave. NewYork: McGraw-Hill, 1959.

Sargent T., Wallace N. Inflation and the government budget constraint // Economic policy in theory and practice. Ed. Razin, Sadka. — L., 1987.

Ajupov A.A., Kazakovtseva M.V. Management of Financial Stability of the Non-Tax Income of Regional Budgets // Procedia - Social and Behavioral Sciences. Volume 131, 15 May 2014, Pages 187-192. 